http://dx.doi.org/10.12775/szhf.2018.059

\title{
Trzy koncepcje zła w myśli filozoficznej oraz religijnej
}

\section{Wprowadzenie}

Problem zła w myśli religijnej i filozoficznej cechuje się wysokim stopieniem aporetyczności. To znaczy, że jest on podejmowany na różne sposoby, które często wzajemnie się wykluczają. Ciężko jest jednoznacznie stwierdzić, który jest tym właściwym, gdyż za każdym $\mathrm{z}$ nich stoją mocne argumenty. Słynny niemiecki filozof Gottfried Wilhelm Leibniz dokonał próby uporządkowania dyskursu związanego $\mathrm{z}$ tą problematyką, proponując trzy perspektywy postrzegania zła:

1) brak porządku w naturze, np. trzęsienia ziemi, powodzie, zarazy, choroby, czyjeś cierpienie (zło fizyczne);

2) brak dobra w postępowaniu człowieka, czyli np. grzech, pycha, złośliwość, kłamstwo, głupota, żądza (zło moralne);

3) ogólny brak jako niedoskonałość człowieka oraz wszelkich innych bytów poza samym Bogiem (zło metafizyczne) ${ }^{1}$.

\footnotetext{
${ }^{1}$ Leibniz, 2001, 80; Bardel, 2006, 37.
} 
Do zaprezentowanego rozróżnienia dokonanego przez Leibniza należy wprowadzić pewną uwagę dotyczącą jego sposobu ujmowania zła metafizycznego, które de facto jest bardziej złem ontologicznym niż metafizycznym. Wedle tego niemieckiego filozofa Bóg stworzył świat najlepszy z możliwych, w którym istnieje wyłącznie niewielki uszczerbek dobra. W swoich rozważaniach traktuje go jako czynnik harmonizujący wszechświat, ponieważ gdyby ten uszczerbek nie istniał, to ludzie nie mogliby dobrze postępować. Problem metafizycznego zła w ujęciu absolutystycznym pozostaje filozoficzną tajemnicą, gdyż argumentacja Leibniza jednych przekonuje, innych zaś nie. Niewątpliwie filozof podążał za koncepcją św. Augustyna, który uwolnił Boga od odpowiedzialności za istnienie $\mathrm{zła}^{3}$.

Zrozumienie odmienności, jaka występuje między złem metafizycznym a złem ontologicznym, wymaga przybliżenia tego, jak powinno się postrzegać zasadę różnicującą dziedzinę metafizyki od dziedziny ontologii. Metafizyka to dziedzina filozoficzna, która zajmuje się badaniem rzeczywistości faktycznie istniejącej, co wcale nie konotuje tego, że ma być to rzeczywistość materialna, gdyż może to być również rzeczywistość duchowa, której nie możemy poznać za pomocą zmysłów. Metafizyka ujmuje różne rejony świata aktualnie istniejącego (dusze, świat materialny, Boga) od strony jego ontycznych racji ${ }^{4}$. Ze względu na fakt odwoływania się dziedziny metafizyki do ontycznych racji zwykło się mówić o złu metafizycznym jako o złu ontycznym. Podkreślmy jeszcze raz, że metafizyka zajmuje się tylko bytami, które postrzega się jako istniejące, obecne. Ontologia zaś podejmuje zagadnienie bytu od strony koniecznych i dostatecznych warunków jego możliwości ${ }^{5}$. W odróżnieniu od metafizyki ontologia zajmuje się bytami nie tylko istniejącymi, obecnymi, ale również możliwymi - niektóre byty są nieobecne, ale dostrzega się, że mają szansę na to, aby się unaocznić oraz urzeczywistnić. Oznacza to, że każda metafizyka jest ontologią, ale nie każda ontologia jest metafizyką. Dla naszych rozważań istotne jest to, że zło metafizyczne to zło jak najbardziej ujmowane i postrzegane jako rzeczywiste. Natomiast zło ontologiczne to zło, które cechuje potencjalność ujawnienia się i urzeczywistnienia, a gdy to już następuje, to staje się ono złem metafizycznym.

\footnotetext{
${ }^{2}$ Rambowicz, 2006, 68.

${ }^{3}$ Ibidem.

${ }^{4}$ Por. Paź 2011, 819.

${ }^{5}$ Ibidem, 819-820.
} 
Nie sposób omówić wszystkich koncepcji związanych z zagadnieniem zła, które pojawiły się na przestrzeni dziejów zarówno w religii, jak i w filozofii. W związku z powyższym ograniczymy się tylko do trzech możliwych ujęć rozpatrywania zła, czyli: zła absolutnego, zła radykalnego i zła banalnego. Zakładamy, że kwestia zła absolutnego to przede wszystkim domena zła ontologicznego oraz metafizycznego. Problematyka zła radykalnego odsyła nas do kategorii moralności. Z kolei zło banalne pozbawione jest jakiegokolwiek założenia o swojej substancjalności, a więc jest przejawem swoistego zła fizycznego.

\section{Zło absolutne jako zło ontologiczne i metafizyczne w myśli filozoficznej i religijnej}

Od czasów starożytnych problematyka zła była żywo i intensywnie komentowana. Platon, wyróżniając ideę Dobra, przyczynił się do rozwoju dyskusji na temat relacji między dobrem a złem na gruncie filozofii. Wśród badaczy myśli platońskiej nie ma jednak zgody co do tego, czy Platon w swej filozofii podejmował wątek zła metafizycznego (ontycznego), czy też zła ontologicznego.

Mieczysław Albert Krąpiec w książce Dzieła. Dlaczego zło? Rozważania filozoficzne stawia tezę, że u Platona występuje kwestia ontologiczności zła ${ }^{6}$. Lubelski filozof opiera swoją argumentację na założeniu, że idei Dobra u Platona nie można utożsamiać $\mathrm{z}$ Bogiem. Mimo że Platon tę ideę przedstawia w samych superlatywach, to nigdy nie nazywa jej Bogiem. Krąpiec podkreśla fakt, że dla Platona bogami były zawsze osoby, które poprzez filozoficzne zrozumienie, odnosząc się do świata idei, ulegały zmianom, a więc należy założyć, że platońska teoria idei również uzasadnia zmienne bóstwa ${ }^{7}$. Dlatego też, zdaniem Krąpca, kwestia dualizmu dobra i zła w myśli platońskiej ujawnia się w koncepcji kosmosu, który według Platona składa się z dwóch pierwiastków: (1) racjonalnego, dobrego i uporządkowanego (świat neotyczny, czyli idee) oraz (2) bezkształtnego, chaotycznego, niepodlegającego w swych

\footnotetext{
${ }^{6}$ Por. Krąpiec 1995, 38-39.

${ }^{7}$ Ibidem, 39.
} 
ostatecznych granicach światu idei (świat zmysłowy, czyli materia) ${ }^{8}$. Krąpiec tak przedstawia swe rozważania:

Rozpatrując te dwa elementy: świat idei i bezkształtną, samą z siebie chaotyczną materię, dostrzegamy, że świat idei jest czymś dobrym, natomiast materia jest właśnie sama z siebie złem i źródłem zła. Ona jest odwieczna i mimo że do pewnych granic podlega Demiurgowi czy sile, idei, to jednak w swym sednie pozostaje sobą, nieracjonalną i złą 9 .

Trzeba podkreślić, że Platon wątku dualizmu dobra i zła jako równorzędnych sił walczących ze sobą nie rozwinął w postaci spójnej teorii. W większym stopniu koncentrował się na złu w odniesieniu do człowieka (teoria duszy ludzkiej). W związku z tym faktem Krąpiec doszukuje się u Platona bardziej zła ontologicznego niż metafizycznego. Jednakże jeśli dokładniej przyjrzeć się samej argumentacji lubelskiego filozofa, a nie jego tezie, to należałoby przyjąć, że postawił niewłaściwą diagnozę w świetle naszego rozróżnienia dziedzin metafizyki i ontologii. Należy sądzić, że u Platona występuje raczej wątek zła metafizycznego niż ontologicznego, starożytny myśliciel bowiem nie zakłada jego potencjalności w świecie zmysłowym.

Tym samym należy uznać, że Platon przyjmuje realnie istniejące zło. Twierdził, że trzeba je ujmować jako siłę destrukcyjną, która niszczy i destabilizuje ład społeczny opierający się na harmonii. Nie twierdził jednak, że zło jest łatwe do rozpoznania i zdefiniowania. Trudność w dostrzeżeniu zła wynika $z$ braku mądrości, tak potrzebnej do poznania świata idei ${ }^{10}$. U Platona pojęcie zła nie jest możliwe do zdefiniowania ze względu na to, że nie posiada ono swej istoty. Zło stoi w opozycji do dobra, gdyż stara się negatywnie wpływać na zastaną rzeczywistość ${ }^{11}$. Jednakże fakt, że jest ono urzeczywistnione $\mathrm{w}$ świecie materialnym, a nie tylko jest potencjalne, musi prowadzić do wniosku, że koncepcja zła w ujęciu Platona jest bardziej metafizyczna niż ontologiczna. Jak już wcześniej zostało zaznaczone ze względu na różne interpretacje Platona, jedni są skłonni twierdzić, że koncepcja zła w filozofii Platona jest bardziej ontologiczna niż metafizyczna, inni zaś odwrotnie ${ }^{12}$.

\footnotetext{
${ }^{8}$ Ibidem.

${ }^{9}$ Ibidem.

${ }^{10}$ Wiśniewski, 1999, 8.

${ }^{11}$ Skrzypek-Faluszczak 2010, 96.

${ }^{12}$ Wśród badaczy polskich myśli Platona za tym, że mamy bardziej do czynienia z koncepcją ontologiczną zła niż metafizyczną opowiada się M.A. Krąpiec, odmiennego zdania jest Jadwiga
} 
Niewątpliwie spór o to, czy pojmowanie zła jest bardziej ontologiczne czy bardziej metafizyczne, nie zmienia faktu, że w literaturze przedmiotu uważa się, że Plotyn z Likopolisu i szkoła neoplatońska jeszcze mocniej „umetafizycznia" Platona, nadając jego systemowi zwartą i konsekwentną postać13. Platon jest interpretowany $\mathrm{w}$ duchu skrajnie intuicjonistycznym i teologicznym. W ramach neoplatonizmu świat postrzegany jest jako hierarchia bytów. Emanują one z Absolutu, czyli bytu doskonałego, którego w żaden sposób nie można poznać rozumowo, gdyż nie jest on ani duchem, ani ideą, lecz czystą jednością - Praj e d n i ą. Naturalną własnością Prajedni jest ekspansja. $\mathrm{Z}$ niej emanują trzy rodzaje światów. Pierwszy to świat ducha - w nim występują idee, które rozum ma możliwość poznać. Drugi to świat duszy obejmujący jednostkowe dusze ludzkie. Trzeci to świat materii, na którym kończy się proces emanacji Prajedni. Świat ducha jest mniej doskonały od Prajedni, świat duszy jest mniej doskonały od świata ducha, a świat materii jest mniej doskonały od świata duszy. Światy te są wzajemnie powiązane, co sprzyja odgadywaniu ziemskiej przyszłości za pomocą astrologii i wróżb. Co więcej, poprzez magię mamy możliwości wpływania na procesy w wyżej położonych światach. Zdaniem Plotyna istnienie zła jest realne, a więc konieczne. Tak przedstawia naturę zła:

Konieczność zła można zaś także pojąć w następujący sposób: skoro nie tylko jest Dobro, to owo promieniowanie z niego lub jeśli ktoś woli tak mówić, owo ustawiczne zastępowanie i odstępowanie musi mieć swój ostatek i ten ostatek, po którym już nic nie może nastać, musi być złem: to co jest Pierwsze, jest z konieczności, a więc i ostatek, nim zaś jest materia, nie posiadająca już nic z dobra. Tak wygląda konieczność zła ${ }^{14}$.

Punkt wyjścia, jaki zaprezentował Plotyn w swej koncepcji emanacji Prajedni, rozwijany był przez jego zwolenników, których nazywa się neoplatończykami. Doprowadzili oni do tego, że w systemie neoplatońskim mistyka odgrywa rolę ważniejszą niż filozofia, gdyż to ona pozwala na zjednoczenie się z najwyższym bóstwem, czyli Prajednią. Największy wkład w uznanie mistyki za ważniejszą od filozofii w doprowadzeniu do powrotu duszy ludzkiej do Prajedni miał myśliciel zwany Jamblichem. Rozwinął on proces emana-

Skrzypek-Faluszczak, która Platonowi przypisuje koncepcję zła metafizycznego (ontycznego), a nie ontologicznego.

${ }^{13}$ Wiśniewski 1999, 8.

${ }_{14}$ Plotyn 1951; cyt. za: Krąpiec 1995, 41. 
cji Prajedni Plotyna, wprowadzając nowe hipostazy mitologicznych bogów, aniołów, demonów i herosów. Twierdził, że bogowie, aniołowie, demony i herosi mogą przez określone zdarzenia być zmuszeni do działania - nazwał to teurgiką ${ }^{15}$. Metody teurgiki miały charakter magiczny i polegały na wcieleniu boskiej siły w różne materialne przedmioty, jak statuetka czy kamień, a nawet w człowieka ${ }^{16}$. Dostrzegamy tu więc nawiązanie do wschodnich religii pogańskich.

Myśl Jamblicha znalazła swoje odzwierciedlenie w myśli manichejskiej, która traktowała świat jako ontologiczną i metafizyczną walkę Dobra ze Złem $^{17}$. Mit manichejski uznaje radykalny dualizm, w którym zakłada się równoważny status Dobra i Zła. To odwieczne i przeciwstawne sobie byty walczące ze sobą o panowanie nad światem. Konsekwencją tego poglądu był radykalny podział ludzi na zbawionych oraz pozostających $\mathrm{w}$ kręgu zła ${ }^{18}$. Przeznaczeni do zbawienia mieli wieść życie na skroś ascetyczne. Nie mogli niszczyć roślin, spożywać mięsa, zanieczyszczać wody, wykonywać pracy fi-

\footnotetext{
${ }^{15}$ Jaroszyński 2000, 104.

${ }^{16}$ Ibidem, 105.

${ }^{17}$ Swoistym traktatem o pochodzeniu Dobra i Zła jest mit manichejski. Dobro i Zło przedstawione są w nim jako „dwie zasady”, przeciwstawne wobec siebie, które nieustanie strukturalizują i porządkują świat, prowadząc walkę między sobą. W micie tym dowiadujemy się, że istnieją dwa Królestwa: Królestwo Światła oraz Królestwo Ciemności (por. Jonas 1994, 224-250). W pierwszym panuje Dobro, w zaś drugim Zło. W manichejskim micie wskazuje się, że Królestwo Światła, w którym panuje Dobro, mieści się na północy. To stamtąd ma emanować Dobro objawiające się w pięciu eonach, którymi są: Rozum, Myślenie, Wgląd, Namysł i Rozwaga. Z kolei południe podlega panowaniu Królestwa Ciemności, które posiada również swoje eony, podobnie jak Królestwo Światła, i są nimi: Dym, Wiatr, Mrok, Żar oraz Woda. Jak zauważa francuski filozof Herve Rousseau, Król Ciemności jest tyranem dla swych podwładnych (Rousseau 1988, 68). Ma o tym świadczyć cytat, który przytacza z Kephalalai: „Władca Królestwa Ciemności zna mowę i język mieszkańców swoich pięciu światów, słyszy wszystko, co wychodzi z ich ust, co mówią jedni do drugich w swoim języku. Wie o każdym planie podejmowanym przeciwko niemu, o każdej podłości knutej przez nich, aby mu zaszkodzić. Nie uniknie mu żadne porozumiewawcze mrugnięcie oczu. Natomiast moce i Archontowie, którzy są mu podlegli, nie rozumieją jego języka [...]. Jego głos jest donośny i przerażający, napawający trwogą jego Moce, a przypomina grzmoty [...]. Kiedy Moce słyszą ten gromopodobny głos, padają na ziemię biją przed nim czołem" (cyt. za: Rousseau 1988, 68).

${ }^{18}$ Pietryga 2003, 31.
} 
zycznej ani zakładać rodziny ${ }^{19}$. Wszystko po to, aby w jak największym stopniu zniwelować styczność ze złem, które ujawniało się w materii ${ }^{20}$.

Według Leszka Kołakowskiego polityka wypływająca z religii manichejskiej była niebezpieczna dla jednostek i społeczeństw, gdyż uznawała zewnętrzny świat za z gruntu zły, co mogło przyczynić się do porzucenia myśli o próbie dokonania w nim czegokolwiek dobrego ${ }^{21}$. Mamy tutaj zatem do czynienia z negacją państwa, ponieważ przymuszałoby ono do styczności ze złem. Innymi słowy wolność dla wyznawców religii manichejskiej identyfikowana była wyłącznie z posłuszeństwem wobec Pana Światła, nie zaś wobec państwa, które było dziełem Króla Ciemności ${ }^{22}$.

Podkreślić należy, że Król Ciemności, występujący w micie manichejskim, jest aktywny w czynieniu zła. To oznacza obecność zła, a nie tylko brak dobra. Wizja zła absolutnego uwalniała człowieka od odpowiedzialności za zło, gdyż za zło na świecie odpowiadały ponadosobowe, nieludzkie siły, jak wspomniany Król Ciemności ${ }^{23}$.

${ }^{19}$ Steven Runciman tak to przedstawia: „Dualizm z konieczności dezaprobuje prokreację biologiczną. Tym samym potępia małżeństwo w o wiele większym stopniu niż przygodne stosunki płciowe, gdyż te ostatnie są tylko odosobnionym grzechem, podczas gdy małżeństwo [zdaniem manichejczyków] jest stanem grzechu. Podobnie akt płciowy przeciwny naturze, jako będący poza ryzykiem prokreacji, był bardziej wskazany niż normalny stosunek między mężczyzną a kobietą. Co więcej, dualistyczny »wierzący« był aż do inicjacji jedynie tworem diabła. Folgowanie żądzom cielesnym nie mogło więc uczynić go gorszym. Czyny zaczynały mieć znaczenie dopiero po inicjacji, kiedy musiał zachować cielesną wstrzemięźliwość i prowadzić życie bezwarunkowo ascetyczne" (por. Runciman 1996, 167).

${ }^{20}$ Pietryga 2003, 30.

${ }^{21}$ Kołakowski 1984, 22, cyt. za: Pietryga 2003, 31-32.

${ }^{22}$ Empirycznym przykładem wpływu religii manichejskiej na wspólnotę polityczną mogą być katarzy, działający od XI do XIII wieku we Francji i Włoszech - negowali całkowicie ustrój feudalny oraz hierarchię kościelną, włącznie z zasadą posłuszeństwa katolickiemu papieżowi, potępiali małżeństwo, a także odmawiali składania przysiąg oraz służenia w wojsku. W literaturze naukowej określani są mianem neomanichejczyków, ponieważ wierzyli w dualną wizję świata, czyli istnienie świata dobrego i złego. Za swoje poglądy katarzy byli prześladowani przez ówczesny Kościół katolicki, który uznał ich za heretyków. Sama nazwa „katarzy” pochodziła od pojęcia greckiego katharoi, co oznaczało „oczyszczenie”. Pragnęli oni oczyścić się ze zła świata materialnego. Przekonani byli, że mityczny Sąd Ostateczny dokonuje się w nas samych, gdy zmagamy się z własnymi słabościami i dokonujemy wyboru między dobrem a złem. Bez względu na to, gdzie się urodziliśmy, w jakiej kulturze wychowaliśmy, jakie obyczaje zostały nam przekazane, w ostateczności wybór własnego losu, to, czy zostaniemy zbawieni, zależy od nas samych (por. Blum 2006, 100-120).

${ }^{23}$ Por. Mikołejko 1998, 71. 
W tym kontekście warto zaznaczyć, że to właśnie religia manichejska dostarczyła fundamenty dla myślenia socjologicznego, w którym dokonywany jest podział ludzi na „my-oni” czy „swój-obcy” jako zamienniki „dobry-zły”. Przejście z myślenia i języka metafizycznego na myślenie i język o charakterze socjologicznym przyczyniło się do wyeliminowania $\mathrm{z}$ dyskursu $\mathrm{w}$ sferze publicznej problematyki zła absolutnego.

\section{Zło moralne jako zło radykalne w różnych perspektywach}

Wraz z pojawieniem się średniowiecznego chrześcijaństwa u schyłku filozofii patrystycznej nastąpił moment przełomowy w refleksji nad złem. Do obszaru rozważań filozoficznych wprowadzono biblijne pojęcie grzechu pierworodnego ${ }^{24}$. Należy w tym miejscu odnieść się do biblijnej historii pierwszych ludzi Adama i Ewy ${ }^{25}$, których stworzył sam Bóg. Jest to jednak inne ujęcie zła niż to zaprezentowane $\mathrm{w}$ micie manichejskim, gdyż zło nie miało jeszcze charakteru realnego, a tylko wyłącznie potencjalny. Prześledźmy W związku z tym kwestię grzechu pierworodnego jako momentu przejścia w myśli filozoficznej i religijnej od zła metafizycznego (realnego) do zła radykalnego o charakterze moralnym, czyli ontologicznego (potencjalnego).

Na początku zło nie było obecne w życiu człowieka, ale było wyłącznie potencjalne. Miało wówczas charakter ontologiczny. W momencie, gdy człowiek, korzystając ze swojej woli zanegował boski porządek świata, a więc złamał boski zakaz, nastąpiło urzeczywistnienie zła. Dlatego zyskało ono cha-

\footnotetext{
${ }^{24}$ Misiak 2009, 33.

${ }^{25}$ Pierwszym miejscem bytowania człowieka był rajski ogród zwany Edenem. Centralnym elementem ogrodu jest drzewo dające wiedzę o dobru i złu. Zaznaczyć należy, że Adam i Ewa byli dziećmi Boga i zostali stworzeni na jego podobieństwo, ale mimo to są od niego różni, gdyż nie są w stanie odróżnić zła od dobra. W tym sensie zło dla Adama i Ewy nie było obecne, a jedynie potencjalne, aż do czasu złamania boskiego zakazu - zakazu spożywania owocu z drzewa poznania dobra i zła. Zakaz ten był swego rodzaju szansą na przestrzeganie Bożego prawa i jego woli, co miało gwarantować szczęście człowieka. Złamanie zakazu spowodowało, że człowiek przestał żyć wiecznie oraz zaczął doświadczać zła w postaci nieszczęść i cierpienia, czyli przede wszystkim zła fizycznego. Kuszona przez węża Ewa zdecydowała się na zerwanie jabłka z drzewa poznania dobra i zła i przekazała je później Adamowi, aby też je skosztował. Spożywanie przez nich zakazanego owocu wskazuje na wspólne złamanie zakazu, a w rezultacie przeciwstawienie się Bogu. Zachowanie to zyskało miano grzechu pierworodnego (Kułaczkowski 2007-2008, 21-27).
} 
rakter radykalny, czyli stało się obecne w świecie ludzkim, ziemskim, lecz nie boskim.

Tego typu interpretacje odnajdujemy w filozofii biskupa z Hippony św. Augustyna, o którym mówi się, że przyczynił się do przezwyciężenia teodycei (uwolnienie Boga od odpowiedzialności za istnienie zła). Uczynił to, stwierdziwszy, że w porządku wszechświata nie ma absolutnego zła, jest jedynie dobro. Innymi słowy człowiek, otrzymawszy dar boski w postaci wolnej woli, mógł wybierać tylko i wyłącznie między większym a mniejszym dobrem. Możliwość podjęcia tego wyboru wprowadzała człowieka w przestrzeń moralności. Jeśli człowiek dokonywał wyboru większego dobra, to jego wybór pokrywał się z wolą Boga, a zatem taki człowiek był moralnie dobry. W przypadku, gdy człowiek dokonywał wyboru mniejszego dobra, to jego wybór nie pokrywał się z wolą Boga, a zatem taki człowiek był moralnie zły. Zdolność człowieka do czynienia zła moralnego jest konsekwencją grzechu pierworodnego, czyli wypowiedzenia posłuszeństwa Bogu ${ }^{26}$.

Należy sobie uświadomić, że w tej perspektywie zło jest tylko zepsuciem dobra. Istnieje wyłącznie mniejsze bądź większe dobro, a więc nie ma absolutnego zła. O tym świadczą słowa św. Augustyna:

Wymieńmy więc dobra, jakie tylko możemy, dobra, za których sprawcę musimy uznawać Boga, i zobaczymy, czy po ich usunięciu ostanie się jakakolwiek natura. Więc wszelkie życie, wielkie i małe, wszelka potęga, wielka i mała, wszelkie zdrowie, wielkie i małe, wszelka pamięć, wielka i mała, wszelka cnota, wielka i mała, wszelki umysł, wieli i mały, wszelki spokój, wielki i mały, wszelkie bogactwo, wielkie i małe, wszelkie czucie, wielkie i małe, wszelkie światło, wielkie i małe, wszelka słodycz, wielka i mała, wszelka miara, wielka i mała, wszelkie piękno, wielkie i małe, wszelki pokój, wielki i mały, i inne podobne rzeczy. Które się mogą tu nasunąć, a zwłaszcza te, które znajdują się we wszystkich stworzeniach zarówno duchowych, jak i cielesnych, więc wszelka miara, piękno i porządek, i wielkie i małe, pochodzą od samego Boga. Ten, kto z tych wszystkich dóbr zechce zrobić użytek, poniesie za to karę na mocy Bożego sądu. Gdzie zaś z tych dóbr nie pozostanie już w ogóle nic, tam też nie pozostanie już żadna natura ${ }^{27}$.

\footnotetext{
${ }^{26}$ Św. Augustyn, 1954, 186.

${ }^{27}$ Ibidem, 174.
} 
Fragment ten informuje nas, że zło w aspekcie globalnym nie ma żadnego oddziaływania na jakość dobra. Ponadto opanowanie przez zło jakiejkolwiek dobrej natury oznacza pozbawienia jej bytu, czyli istnienia.

Inną perspektywę zła radykalnego proponuje Immanuel Kant, który nie bardzo chciał wikłać się w metafizyczne rozważania na temat istnienia Boga. Przyjmuje on, że Bóg jest rzeczą samą w sobie, a właściwie jest ideą wytworzoną przez czysty rozum spekulatywny. Ludzie, zdaniem tego myśliciela, odczuwają potrzebę poznania Boga, lecz muszą zdać sobie sprawę, że jest to niemożliwe. Tak to Kant przedstawia w Krytyce czystego rozumu:

W ten sposób transcendentalne i jedyne określone pojęcie, jakiego dostarcza nam czysty spekulatywny rozum o Bogu, jest w najściślejszym sensie deistyczne, tj. rozum nie dostarcza nam nawet obiektywnej ważności takiego pojęcia, lecz tylko ideę czegoś, na czym wszelka realność empiryczna opiera swą najwyższą i konieczną jedność i co możemy sobie pomyśleć tylko w analogii do rzeczywistej substancji, która w myśli praw rozumu byłaby przyczyną wszelkich rzeczy ${ }^{28}$.

Umiejscowienie Boga w paradygmacie rozumu praktycznego, a nie spekulacyjnego, miało na celu uwolnienie człowieka od autorytetu zewnętrznego, a wiec od samego Boga.

$\mathrm{Na}$ tej podstawie Kant formułuje pojęcie zła radykalnego, dystansując się od zła absolutnego ${ }^{29}$. Wskazuje, ze zło radykalne nie jest złem metafizycznym. W jego ujęciu należy je postrzegać wyłącznie jako stałą możliwość odstępstwa od prawa moralnego. Nie stara się on identyfikować zła z brakiem bytu bądź nicością, jak to jest w przypadku zła absolutnego. Jego zdaniem to w naturze ludzkiej należy doszukiwać się źródeł zła radykalnego ${ }^{30}$. Warto przytoczyć, w jaki sposób filozof z Królewca ujmuje naturę ludzką:

przez naturę człowieka rozumiemy tutaj jedynie subiektywną podstawę używania wolności w ogóle (podległą obiektywnym prawom moralnym), która

\footnotetext{
${ }^{28}$ Kant $1957,418$.

${ }^{29}$ Drwięga 2012, 181.

${ }^{30}$ Jak zauważa Mirosław Żelazny, terminu „radykalny” użytego przez I. Kanta nie należy rozumieć tak samo, jak ma to miejsce w języku potocznym, czyli jako „zasadniczy”, „gruntowy”, „bezkompromisowy”, ale należy się odnieść do źródłosłowu: radix oznacza „korzeń”. „Radykalny” w tym ujęciu jest bliższy znaczeniu „źródłowy” (por. Żelazny 1993, 107).
} 
poprzedza każdy postrzegany czyn - nie ma więc znaczenia, gdzie leży ta podstawa $^{31}$.

Z tego fragmentu nie wynika, że człowiek u Kanta jest z natury zły - zło jest wobec niego immanentne, wrodzone.

Należy stwierdzić, że filozof niemiecki jest konsekwentny w swych rozważaniach - tak jak nie możemy stwierdzić, czy Bóg istnieje, czy nie, tak też nie możemy jednoznacznie orzec, czy człowiek jest z natury dobry, czy zły. Mówiąc o naturze ludzkiej jako źródle zła radykalnego, Kant ma na myśli tylko tyle, że człowiek posiada pewne skłonności do zła. W swoim dziele Religia $w$ obrębie rozumu wypowiada się następująco:

Kiedy zatem mówimy: człowiek jest z natury dobry, albo z natury zły, oznacza to tyle: człowiek ogólnie, posiada w sobie jakąśs (niemożliwą do zbadania przez nas) pierwotną podstawę umożliwiającą przyjmowanie dobrych albo złych (sprzecznych z prawem) maksym, przez to wyraża się równocześnie właściwości jego gatunku ${ }^{32}$.

Zdaniem Kanta człowiek powinien liczyć przede wszystkim na swój rozum praktyczny. To znaczy, że w dążeniu do zbawienia powinien się kierować wyłącznie wolną wolą, która umocowana powinna być w sferze moralnego sumienia. Wówczas to wolna wola prowadziłaby człowieka do wolności, a więc czyniłaby go dobrym. Natomiast jeśli wolna wola nie jest umocowana w sferze moralnego sumienia, to człowiek posiadałby swobodę działania, lecz nie byłby dobry. Warto w tym miejscu wyraźnie podkreślić, że wolna wola (Willkur) może prowadzić do zła radykalnego albo do dobra moralnego. Jeśli wolna wola realizuje powinności, wprowadza człowieka w przestrzeń moralną, i wówczas wolna wola okazuje się dobrą wolą (Wille). Jednakże człowiek, używając wolnej woli, może odrzucić swoje powinności, a więc może odrzucić prawo moralne. W takim przypadku wolna wola nie staje się dobrą wolą. Oznacza to, że źródło zarówno zła, jak i dobra Kant upatruje w możliwości wyboru, czyli w wolnej woli. Jeśli wolna wola kieruje się imperatywem kategorycznym, to staje się dobrą wolą, gdy zaś go kwestionuje i nie zamierza realizować - jest złą wolą ${ }^{33}$. Tak o tym wyraża się niemiecki filozof:

\footnotetext{
${ }^{31}$ Kant 1993, 41.

${ }^{32}$ Ibidem.

${ }^{33} \mathrm{Na}$ temat rozróżnienia terminologicznego między pojęciami: Willkur i Wille, których używa I. Kant, warto zapoznać się z sugestiami interpretacyjnymi Żelaznego 1993, 107.
} 
każdy zły czyn, jeżeli szukamy dla niego rozumowego źródła, musi być traktowany tak, jak gdyby człowiek dokonał go [wychodząc] bezpośrednio ze stanu niewinności. Jakkolwiek byłoby jego poprzednie zachowanie, jakkolwiek naturalne przyczyny wewnętrzne lub zewnętrzne wpływałyby na niego, to postępowanie człowieka jest wolne i niezdeterminowane przez żadną z tych przyczyn. Może więc i musi być zawsze oceniane jako pierwotne użycie jego woli ${ }^{34}$.

Filozof z Królewca wyraża się jasno w tej kwestii, twierdząc że nic nie jest złe (a więc nie ma zła metafizycznego), zły jest tylko nasz własny czyn (a więc mamy do czynienia ze złem radykalnym wynikającym z wolnej woli) ${ }^{35}$.

Pojęcie Boga jako idei regulatywnej ma pomóc człowiekowi w doskonaleniu moralnym. Innymi słowy Bóg w myśli kantowskiej jest jedynie postulowany, by człowiek mógł samodzielnie uzyskać dzielność etyczną. Zły człowiek w kantowskiej filozofii musi posiadać świadomość istnienia prawa moralnego i z premedytacją łamać je w wyniku swego działania. Zło powoduje, że człowiek przestaje słuchać własnego sumienia. Stanowisko Kanta w stosunku do manichejskiej wizji świata należy uznać za umiarkowane, gdyż zło wiąże on tylko i wyłącznie $\mathrm{z}$ faktem postrzegania człowieka jako istoty z natury skłonnej do złego postępowania, lecz materia, która go otacza, a więc również jego własne ciało, nie jest z gruntu zła. Ponadto Kant uwalnia się od postrzegania człowieka jako z góry przeznaczonego do zbawienia przez Boga (idea predestynacji św. Augustyna), w pełni czyni go odpowiedzialnym za swe czyny.

\section{Zło banalne jako słaba wola mocy}

Proces banalizacji zła prawdopodobnie rozpoczął się wraz z twierdzeniem Fryderyka Nietzschego, że Bóg w sensie ontologicznym umarł ${ }^{36}$. Człowiek znalazł się poza dobrem i złem ${ }^{37}$. W swoich rozważaniach filozof ten wskazywał, że wszelkie rozróżnienie pomiędzy dobrem a złem jest wytwarzane przez kulturę w celu realizacji jej interesów. Doszło bowiem do przewartościowania wartości, czego konsekwencją stało się funkcjonowanie fałszywych

\footnotetext{
${ }^{34}$ Kant 1993, 63.

${ }^{35}$ Ibidem, 52.

${ }^{36}$ Por. Nietzsche 2008, 8; Nietzsche, 2003, 101.

${ }^{37}$ Por. Nietzsche, 2010.
} 
przekonań na temat tego, co dobre, a co złe. Dla Nietzschego fałszywymi wartościami są te odwołujące się do sprawiedliwości, altruizmu, litości czy też prymatu dóbr duchowych. Natomiast prawdziwymi wartościami są te odwołujące się do afirmacji wartości życia, aprobaty dla wolności i nierówności ${ }^{38}$.

Sam Nietzsche nie sformułował pojęcia zła banalnego, ale niewątpliwie przyczynił się do rozwoju tej idei. Można powiedzieć, że człowiek pozbawiony intelektualnego sumienia egzystuje w przestrzeni zła banalnego. Przypomnijmy, że według Nietzschego wolnym człowiekiem jest ten, kto za sprawą woli mocy podejmuje trud radzenia sobie z własnymi instynktami. Jeśli czyni to za sprawą czegoś zewnętrznego, np. za sprawą bezrefleksyjnie przyjętego systemu wartości, w którym został wychowany, to pozbawiony jest intelektualnego sumienia. Filozof pisze:

Uważa się on bowiem za wolnego, a jest tylko nakręconym mechanizmem zegara, niezdolnym choćby tylko wyraźnie dostrzec ten mechanizm, nie mówiąc już o jego zmianie na swój sposób i w pożądanym przez niego kierunku³9.

Człowiek rezygnujący z owej walki z samym sobą bądź nieumiejący jej prowadzić tkwi w „moralności niewolniczej”, gdyż posługuje się racjonalnością instrumentalną, zamiast stworzyć własną racjonalność aksjologiczną ${ }^{40}$. Instrumentalnie przyjmuje system wartości, by być postrzeganym jako człowiek cnotliwy, a zyskawszy takie miano, tkwi w złudnym poczuciu szczęścia, gdyż rezygnuje sam z siebie, oddając się we władanie stada ${ }^{41}$. Natomiast człowiek wolny to ten, kto za sprawą swej woli mocy wytwarza własną racjonalność aksjologiczną, która umożliwiała mu osiągnięcie „autonomii moralnej”.

Należy podkreślić, że pojęcie zła banalnego wprowadziła do swoich filozoficznych rozważań Hannah Arendt, która swoje dzieła tworzyła w XX wieku ${ }^{42}$. Trudno stwierdzić, czy wcześniej dostrzeżono pewne związki zachodzące między jej myślami a myślą Nietzschego, jednak zanim posłużyła się tym pojęciem, operował kantowskim terminem "zła radykalnego", ale stosowała je w innym kontekście. Opisując zjawisko zła radykalnego, odwoływała się do konkretnych współczesnych przykładów, zwłaszcza do

\footnotetext{
${ }^{38}$ Por. Tyburski, Wachowiak, Wiśniewski, 1997, 468.

${ }^{39}$ Nietzsche, 2004, 272.

${ }^{40}$ Nietzsche 2010, 101.

${ }^{41}$ Wróbel 2011, 23.

${ }^{42}$ Por. Arendt 2000; Arendt 1993; Arendt, 2007; Arendt 1998; Arendt 2003; Arendt 2007; Arendt 1999.
} 
dwudziestowiecznych totalitaryzmów ujawniających coraz to nowsze postacie zła. Ważnym elementem rozważań Arendt nad złem radykalnym stało się pojęcie totalnego panowania ${ }^{43}$. Miało ono na celu dokonanie całkowitej eliminacji różnorodności oraz odmienności ludzi, aby w rezultacie stali się oni tacy sami. Jest to możliwe do osiągnięcia wówczas, gdy ubezwłasnowolni się do takiego stopnia myślenie człowieka, by jego działania sprowadzały się wyłącznie do czystych odruchów. W tym momencie należy dostrzec zachodzące paralele między myślą Arendt i Nietzschego. Krytykowali oni „totalne panowanie” rozumiane jako próba „zniewolenia człowieka” za pomocą narzuconego systemu wartości. Ponadto oboje postrzegają wolność człowieka w kontekście wolności negatywnej. Podkreślić należy, że różnica między nimi przejawia się jedynie w tym, że negatywna wolność człowieka u Nietzschego jest totalna, znajduje się bowiem poza wszelką wspólnotą polityczną, podczas gdy u Arendt nie ma takiego charakteru, bo ujawnia się we wspólnocie politycznej, w której jednostka ma zachować swoją autonomie ${ }^{44}$.

W konsekwencji owego panowania siła ludzkiego sumienia stała się niejednoznaczna oraz możliwa do zakwestionowania. Teoria zła radykalnego Arendt uznawana jest przez takich myślicieli jak Hans Jonas, Emmanuel Levinas czy Jean Nabert za przekroczenie kantowskiego pojęcia zła radykalnego, określonego mianem zła metafizycznego ${ }^{45}$. Wszakże Kant, jak to wcześniej było podkreślone, nie opowiadał się za złem w rozumieniu metafizycznym, tylko ontologicznym. Można powiedzieć, że Arendt nie odrzuca całkowicie zła radykalnego w ujęciu Kantowskim, lecz wskazuje, że zła nie można utożsamiać wyłącznie ze świadomym i racjonalnym odstępstwem od prawa moralnego. Zło o charakterze banalnym wynika z bezmyślności, która konotuje całkowite zawieszenie „człowieczeństwa”, tak jakby moralność w ogóle nie istniała. Tutaj należy dostrzec różnice w pojmowaniu zła między Kantem a Arendt. U Kanta zło radykalne ma miejsce wówczas, gdy wolna wola odrzuci prawo moralne (imperatyw kategoryczny). Podczas gdy u Arendt człowiek, posługując się wolną wolą, może nawet nie dostrzegać imperatywu kategorycznego, a to oznacza, że nie ma sytuacji jego odrzucenia. Innymi słowy zło w ujęciu Arendt nie było tylko odstępstwem od prawa moralnego,

\footnotetext{
${ }^{43}$ Drwięga, 2012, 189-190.

${ }^{44}$ Według H. Arendt zapewnienie przestrzeni dla funkcjonowania pluralizmu światopoglądowego gwarantuje wolność człowieka. Polityka dopuszczająca ten pluralizm jest istotą wolności. Tak to przedstawia: „Wolność istnieje tylko w owej jedynej w swoim rodzaju pośredniczącej między ludźmi przestrzeni politycznej” (Arendt 2007, 126).

${ }^{45}$ Drwięga 2012, 199-200.
} 
lecz przekraczało wszelkie możliwe granice. Świadczyć o tym miały czyny dokonywane w obozach koncentracyjnych, gdyż w żaden sposób nie są one możliwe do usprawiedliwienia. Owo zło przekroczyło wszelkie kategorie moralności, stając się złem niepojmowalnym.

Hanna Arendt w swoich początkowych rozważaniach nad kwestią zła przyjęła za punkt wyjścia zło radykalne, aby z czasem dokonać transformacji tegoż zjawiska, czyli wspomnianej banalizacji zła. Przełomem w postrzeganiu zła przez Arendt był proces Adolfa Eichmanna, który ujawnił przed nią nowy, odmienny aspekt zła ${ }^{46}$. Wskazywała na to, że mimo okrucieństw, których się dopuścił, nie dostrzegała w nim nic szczególnego. Nie dostrzegała bowiem demoniczności jego postaci w odniesieniu do popełnionych przez niego okrutnych zbrodni. To spowodowało, że dostrzegła banalność zła, która tak naprawdę przejawia się w ludzkiej bezmyślności. Pisze o tym tak:

Uważam obecnie, iż zło nigdy nie jest „radykalne”, a tylko skrajne i że nie posiada ono żadnej głębi ani jakiegokolwiek demonicznego wymiaru. Może ono wypełnić i spustoszyć cały świat, bo rozprzestrzenia się jak grzyb porastający powierzchnię, „urąga myśli", jak napisałam, gdyż myśl próbuje dostrzec pewną głębokość, sięgnąć do korzeni, w momencie zaś, gdy zajmie się złem, jałowieje, bo dotyka nicości. Na tym polega „banalność zła” ${ }^{\text {”77 }}$.

To właśnie ta bezmyślność była przyczyną powstawania nieludzkich zachowań w czasie wojen światowych. Dostrzegała zatem, że zło tak naprawdę nie posiada żadnego szatańskiego wymiaru. Oznacza to, że myśl ludzka, sięgając do pojęcia zła, wyzbywa się istotności na rzecz jałowej banalności. Zdaniem Hanny Arendt tylko dobro można postrzegać w kategoriach radykalności czy też głębokości ${ }^{48}$. Przyjmując tok rozumowania autorki Kondycji ludzkiej, można powiedzieć, że zło nie jest żadnym autonomicznym bytem, który można określić jako zły - jedynie czyny można rozumieć jako złe ${ }^{49}$. Tym samym w kwestii źródła zła zgadza się ona $\mathrm{z}$ filozofem z Królewca. Jednakże uważa ona, że zło nie jest już radykalne, ale ekstremalne, ponieważ może przyjmować skrajną postać, a jego zasięg oddziaływania może być ogromny. Może ono „zaistnieć” tylko i wyłącznie kosztem czegoś, więc żeruje na czymś, gdyż nie jest w stanie samoistnie powstać. Zło banalne żeruje zatem na ludz-

\footnotetext{
${ }^{46}$ Arendt 1998, 324-325.

${ }^{47}$ Zobacz odpowiedź H. Arendt na list Gershoma Scholema: Arendt 1998, 401.

${ }^{48}$ Ibidem.

${ }^{49}$ Drwięga 2012, 199-200.
} 
kiej bezmyślności, która wyłącza całkowicie elementarne odczucia człowieczeństwa, jak np. szacunek dla drugiego człowieka i uznanie jego godności. Człowieka bezmyślnego, który jest narzędziem w urzeczywistnianiu zła banalnego, nie dotykają żadne wyrzuty sumienia, ponieważ nie kieruje się on żadnym prawem moralnym.

\section{Podsumowanie}

Zło jest zjawiskiem wieloaspektowym, dlatego trudno ten termin osadzić w ramach jednej, spójnej definicji, która usatysfakcjonowałaby wszystkich. Jego wszechobecność można rozpatrywać zarówno pod kątem metafizycznym (jako zło realnie istniejące), jak i za pomocą czysto teoretycznych źródeł (jako zło potencjalnie istniejące). W pierwszym przypadku badanie zła będzie wiązało się przede wszystkim ze sposobem kosmogenicznego postrzegania świata, tak jak to miało miejsce w religii manichejskiej (Bóg Światła - Bóg Ciemności). Podczas gdy drugie ujęcie może uwzględniać kosmogeniczne postrzeganie świata, ale nie musi, gdyż w większym stopniu koncentrować się będzie na występowaniu zła w świecie ludzkim.

Zło ma niebagatelną siłę oddziaływania, gdyż wnika we wszystkie sfery egzystencjalne człowieka. Funkcja zła to wywoływanie bólu i cierpienia, jednak owe stany emocjonalne każda jednostka odczuwa zupełnie inaczej oraz w innym stopniu natężenia. Przez to jego funkcja zostaje skrupulatnie rozmyta i - jak się łatwo domyślić - bliżej nieokreślona. Jak zatem można starać się badać zło mimo owych przeszkód? Należy skorzystać z różnorodnych koncepcji oscylujących wokół tej problematyki i czerpać z dorobku filozoficznego oraz religijnego.

Na koniec warto zaznaczyć momenty przełomowe, które przyczyniły się do powstania koncepcji zła radykalnego i zła banalnego niejako w opozycji do zła absolutnego. W kulturze zachodniej takim historycznym momentem „rezygnacji” ze zła absolutnego na rzecz zła radykalnego należałoby uznać oświecenie, które doprowadziło do obalenia ustroju feudalnego. Wszakże to już św. Augustyn zrywa z tradycją zła absolutnego, umieszczając zło w wolnej woli człowieka jako wybór mniejszego zła, to jednak w oświeceniu dostrzec można dopiero "całkowitą rezygnację” z metafizyki zła absolutnego. Dzieje to się to m.in. za sprawą filozofii Kanta, który Boga traktuje jako ideę regulatywną. Innymi słowy, Bóg zaczyna istnieć w świadomości ludzkiej jako 
potencjalność, a nie faktyczność. Ponadto filozof ten nie odwołuje się ani do idei łaski, ani do idei predestynacji, lecz czyni człowieka całkowicie odpowiedzialnym - za sprawą jego wolnej woli - za istnienie zła moralnego, tylko bowiem takie istnieje. Natomiast przejście od zła radykalnego do zła banalnego wiąże się z myślą Nietzschego, który „uśmierca Boga”, a więc Bóg nie jest już ani realny, ani potencjalny. Pojawienie się zła banalnego było ściśle związane z doświadczeniem barbarzyństwa. Holocaustu, którego przyczyną była bezmyślność osób dopuszczających się tej zbrodni.

\section{Bibliografia}

Arendt Hannah. 1993. Korzenie totalitaryzmu, cz. I, tłum. Mariola Szawiel, Daniel Grinberg. Warszawa: Wydawnictwo Niezależna Oficyna Wydawnicza, Seria Kwartalnika Politycznego „Krytyka”.

Arendt Hannah. 1998. Eichmann w Jerozolimie: rzecz o banalności zła, tłum. Adam Szostkiewicz. Kraków: Społeczny Instytut Wydawniczy Znak.

Arendt Hannah. 1999. O przemocy, tłum. Anna Łagodzka, Wojciech Madej. Warszawa: Fundacja Aletheia.

Arendt Hannah. 2000. Kondycja ludzka, tłum. Anna Łagodzka. Warszawa: Wydawnictwo Alatheia.

Arendt Hannah. 2003. O rewolucji, tłum. Mieczysław Godyń. Warszawa: Czytelnik.

Arendt Hannah. 2007. Polityka jako obietnica, tłum. Wojciech Madej, Mieczysław Godyń. Warszawa: Pruszyński S-ka.

Arendt Hannah. 2008. Korzenie totalitaryzmu, cz. II, tłum. Mariola Szawiel. Warszawa: Wydawnictwo Akademickie i Profesjonalne.

Augustyn. 1954. Dialogi i pisma filozoficzne, t. IV, O naturze dobra, tłum. Maria Maykowska. Warszawa: PAX.

Bardel Michał. 2006. „Metafizyczny skandal zła”, Znak 9:35-47.

Blum Jean. 2006. Katarzy. Od Grala do sekretu dobrej śmierci, tłum. Alicja Żuchelkowska. Poznań: Wydawnictwo Vesper.

Drwięga Marek. 2012. Człowiek między dobrem a złem. Studia z etyki wspótczesnej. Kraków: Księgarnia Akademicka.

Jaroszyński Piotr. 2000. „Meandry neoplatonizmu”, Człowiek w Kulturze. Pismo poświęcone filozofii i kulturze 13 : 97-107.

Jonas Hans. 1994. Religia gnozy, tłum. Marek Klimowicz. Kraków: Wydawnictwo Platan.

Kant Immanuel. 1957. Krytyka czystego rozumu, t. II, tłum. Roman Ingarden. Warszawa PWN. 
Kant Immanuel. 1993. Religia w obrębie samego rozumu, tłum. Aleksander Bobko. Kraków: Wydawnictwo Znak.

Kołakowski Leszek. 1984. Czy diabeł może być zbawiony i 27 innych kazań. Londyn: Aneks.

Krąpiec Mieczysław Albert. 1995. Dzieła. Dlaczego zło? Rozważania filozoficzne. Lublin: Wydawnictwo Katolickiego Uniwersytetu Lubelskiego.

Kułaczkowski Jerzy. 2007-2008. „Grzech pierworodny i jego następstwa dla relacji pomiędzy mężczyzną a kobietą w świetle Księgi Rodzaju (Rdz 3)”, Studia Warmińskie XLIV-XLV : 17-34.

Leibniz Gottfried Wilhelm. 2001. Teodycea. O dobroci Boga wolności człowieka i pochodzeniu zła, przeł. Małgorzata Frankiewicz. Warszawa: PWN.

Mikołejko Zbigniew. 1998. Mity tradycjonalizmu integralnego. Julius Evola i kultura religijno-filozoficzna prawicy. Warszawa: IFiS PAN.

Misiak Rafał. 2009. „Geneza zła w filozofii Sorena Kierkegaarda”, Analiza i Egzystencja $10: 33-54$.

Nietzsche Friedrich. 2003. Wiedza radosna, tłum. Leopold Staff. Kraków: Zielona Sowa.

Nietzsche Friedrich. 2004. Pisma pozostałe, tłum. Bogdan Baran. Kraków: Inter Esse.

Nietzsche Friedrich. 2008. Tako rzecze Zaratustra, tłum. Wacław Berenet. Kraków: Hachette.

Nietzsche Friedrich. 2010. Zmierzch bożyszcz, czyli jak filozofuje się młotem, tłum. Stanisław Wykrzykowski. Łódź-Wrocław: Nietzsche Seminarium.

Nietzsche Friedrich. 2010. Poza dobrem i złem, tłum. Stanisław Wykrzykowski. Łódź-Wrocław: Nietzsche Seminarium.

Paź Bogusław. 2011. „Ontologia versus metafizyka? Geneza, rozwój i różne postaci nowożytnej teorii bytu”, Filo-Sofija 15 : 817-847.

Pietryga Anna. 2003. „Opozycja homo-animal a manicheizm”, Acta Universitatis Wratislaviensis $15: 27-32$.

Plotyn. 1951. Enneady, tłum. Adam Krokiewicz. Warszawa: PWN.

Rambowicz Piotr. 2006. „Leibniz kontra tsunami”, Znak 9 : 62-79.

Rousseau Harvé. 1988. Bóg zła, tłum. Anna Kotalska. Warszawa: Czytelnik.

Runciman Steven. 1996. Manicheizm średniowieczny, tłum. Jerzy Prokopiuk, Bartłomiej Zborski. Gdańsk: Marabut.

Skrzypek-Faluszczak Jadwiga. 2010. Ocalenie od zła $w$ filozofii Platona. Kraków: WAM.

Tyburski Włodzimierz, Andrzej Wachowiak, Ryszard Wiśniewski. 1997. Historia filozofii $i$ etyki. Toruń: TNOiK Dom Organizatora.

Wiśniewski Ryszard. 1999. „O przedmiocie i metodach filozofii zła”. W Studia dziejów filozofii zła, red. Ryszard Wiśniewski. 5-13. Toruń: Wydawnictwo UMK.

Wróbel Szymon. 2011. „Nihiliści polityczni”, Przegląd Polityczny 107 : 22-28.

Żelazny Mirosław. 1993. Idea wolności w filozofii Kanta. Toruń: Comer. 


\section{Streszczenie}

\section{Trzy koncepcja zła w myśli filozoficznej oraz religijnej}

Artykuł prezentuje w sposób syntetyczny trzy sposoby rozumienia zagadnienia zła, wykształcone na przestrzeni dziejów w myśli filozoficznej oraz religijnej. Na początku dominowało postrzeganie zła jako czegoś absolutnego, następnie od czasów filozofii I. Kanta przewagę zyskuje myśl o złu ograniczonym do kontekstu moralnego - i ten typ zła w filozofii określamy mianem zła radykalnego. Z kolei H. Arendt, dokonując interpretacji filozofii F. Nietzschego w kontekście procesu A. Eichmanna, wprowadza koncepcję zła banalnego, które abstrahuje od aspektu moralnego, umieszczając je w wymiarze działań człowieka i jego egzystencji w przestrzeni społecznej i politycznej.

Słowa kluczowe: zło absolutne; zło radykalne; zło banalne; dobro; moralność.

\section{Abstract \\ Three Concepts of Evil in Philosophical and Religious Thought}

The article presents a synthetic analysis of three ways in which evil was understood over centuries in philosophical and religious thought. First, evil was construed as something absolute. Then, since the times of I. Kant it has been predominantly limited to the moral content. This type of evil is referred to in philosophy as radical evil. H. Arendt, when interpreting F. Nietzsche's philosophy in the context of A. Eichmann process, introduced the notion of banal evil that disregards the moral context and places evil in the context of human actions and his or her existence in social and political space.

Keywords: absolute evil; radical evil; banal evil; good; morality. 